replacement of all pews in an unlisted church with chairs and the introduction of a carpet over a period of six months. The work had not been completed owing to lack of funds. The chancellor directed that a fresh public notice should be displayed due to the lapse of time. Despite objections being received, the chancellor granted an extension of time because the change was justified by the greater flexibility created for mission, worship and community use. [Catherine Shelley]

\title{
Re St Paul, Woldingham
}

Southwark Consistory Court: Petchey Ch, 26 June 2012 Telecommunications installation - licence fees

The petition of the team vicar and churchwardens sought a faculty to permit (1) the installation of telecommunications equipment (a mobile phone base station') in the bell chamber of a church and (2) the team vicar and PCC to enter into a licence agreement with New Edge Telecommunications (Net) Limited (NET) to maintain and operate and use the equipment. The proposed licence agreement was for a period of 20 years with an annual fee of $£ 5,000$, which was to be reviewed every five years to reflect the fee payable in the open market. Local opinion was divided on the proposals. A number of objections, including one from the governors of the local primary school, were received. Following Re Emmanuel Church, Bentley [2006] Fam 39, the court would not apply stricter requirements relating to health and safety risks than those of the Government and local planning authorities. The relevant policy in the National Planning Policy Framework was that local planning authorities 'should not seek ... to determine health safeguards if the proposal meets International Commission guidelines for public exposure'. The proposal in the petition met those guidelines. Accordingly, the health concerns that were raised by objectors did not provide a basis for refusing the petition. Objections that the equipment would facilitate the transmission of pornography could not be sustained in the light of Re St Peter and St Paul, Chingford [2007] Fam 67. As to the proposed licence agreement, the chancellor was concerned that NET was effectively a monopoly purchaser of the right to put telecommunications equipment in churches. In practice, the petitioners were not in a position to sell the right to install the equipment to anyone other than NET so that their bargaining power was constrained. The annual fee of $£ 5,000$ was near the bottom of the scale in the chancellor's experience but it was the best price that could be achieved in an imperfectly operating market. That being so, the chancellor identified as a matter of concern the adequacy of the way in 
which market value would be assessed at the five-yearly reviews of the licence fee. The fact that, as a result of provisions in the Telecommunications Code (Schedule 2 to the Telecommunications Act 1984), the equipment might well remain in place beyond the 20-year term of the licence, possibly even without a further faculty, meant that in the future the licence fee payable might become very small in real terms. Accordingly, while the chancellor did envisage granting a faculty as sought, it would not be granted until he had received satisfactory answers to the concern he had raised. [Alexander McGregor]

\title{
Re St Thomas, Kilnhurst
}

Sheffield Consistory Court: McClean Ch, 11 July 2012 Gravestones - replacement - duties of incumbent

Fifty-five years after the deceased's death, the petitioner's aunt had replaced the gravestone over the deceased's grave with one that omitted reference to the deceased's wife and son. The deceased's son petitioned to remove the replacement and erect a replica of the original stone, which had unfortunately been destroyed. The incumbent at the time had made inadequate checks when granting the application for the second headstone and as such had not appreciated that it was a replacement stone. The chancellor noted that the owner of a headstone is the person who commissioned and paid for it and, upon their death, the heir-at-law of the person commemorated. Incumbents have a duty to make appropriate checks in relation to applications to erect a gravestone, to check that the applicant has standing to make the application. A faculty was issued to allow removal of the second headstone and its replacement with a replica of the original. [Catherine Shelley]

doi:10.1017/So956618X12001032

\author{
JGE v Portsmouth Roman Catholic Diocesan Trust \\ Court of Appeal: Ward, Tomlinson and Davis LJJ, 12 July 2012 \\ [2012] EWCA Civ 938 \\ Vicarious liability-diocese-priest
}

The Portsmouth Roman Catholic Diocesan Trust appealed against a decision of the High Court that it was vicariously liable for the torts allegedly committed by a parish priest in their diocese. In a majority judgment the court dismissed the 